\title{
Effect of Information Capital Readiness on Business Performance in Indonesian MSMEs: Does Online Market Orientation Matter?*
}

\author{
Bambang TJAHJADI ${ }^{1}$, Noorlailie SOEWARNO ${ }^{2}$, Gabriella Monica GUNAWAN ${ }^{3}$ \\ Received: September 01, 2020 Revised: October 26, 2020 Accepted: November 05, 2020
}

\begin{abstract}
The focus of this study is to investigate the mediating role of online market orientation on information capital readiness-business performance relationship. The construct of information capital readiness is rarely researched. The readiness here refers to the availability of information capital needed to support strategy execution. As quantitative research, this study employs the partial least squares structural equation modeling (PLS-SEM) to test the hypotheses. Data was collected using questionnaires from the owners/managers of the micro, small, and medium-sized enterprises (MSMEs) in the East Java Province, Indonesia. As many as 433 respondents had participated. The result indicates that information capital readiness directly and positively affects business performance. Further analysis reveals that online market orientation partially mediates information capital readiness-business performance relationship. In conclusion, this study suggests that the owners/managers of the MSMEs should improve their information capital readiness to support online market orientation strategy so that it can improve their business performance. This is the first study that brings together the issues of information capital readiness and online market orientation as the antecedents of business performance in the Indonesian MSMEs research setting. The mediating role of online market orientation is rarely explored in previous studies.
\end{abstract}

Keywords: Information Capital Readiness, Online Market Orientation, Business Performance, MSMEs

JEL Classification Code: D22, L26, L21, L22, M31

\section{Introduction}

Almost in every country, MSMEs play an important role in the national economy. They contribute to economic

\footnotetext{
*Acknowledgements:

The authors would like to express their deep gratitude to the Ministry of Education and Culture, the Republic of Indonesia for providing this research grant, and to Universitas Airlangga for facilitating the administration for this research.

${ }^{1}$ First Author and Corresponding Author. Lecturer, Department of Accounting, Faculty of Economics and Business, Universitas Airlangga, Indonesia [Postal Address: Penjaringansari PS II G/24, Rungkut, Surabaya, East Java, 60297, Indonesia]

Email: bambang.tjahjadi@feb.unair.ac.id

${ }^{2}$ Lecturer, Department of Accounting, Faculty of Economics and

Business, Universitas Airlangga, Indonesia.

Email: noorlailie-s@feb.unair.ac.id

${ }^{3}$ Department of Accounting, Faculty of Economics and Business, Universitas Airlangga, Indonesia.

Email: gabriella.monica.gunawan-2016@feb.unair.ac.id

(c) Copyright: The Author(s)

This is an Open Access article distributed under the terms of the Creative Commons Attribution Non-Commercial License (https://creativecommons.org/licenses/by-nc/4.0/) which permits unrestricted non-commercial use, distribution, and reproduction in any medium, provided the original work is properly cited.
}

growth and the equitable distribution of development. The improved performance of MSMEs is also crucial for the growth of the national industry, especially in the era of global competition. Thus, MSMEs must continually strive to improve their competencies to win the competition (Napitupulu et al., 2018).

An organization consists of a set of resources and management capabilities that make it possible to exploit market opportunities to improve organizational performance (Lioukas, Reuer, \& Zollo, 2016). The resource-based view (RBV) states that assets, capabilities, organizational processes, attributes, knowledge, information, and anything under the company's control allow a company to efficiently and effectively implement its strategy. Information capital readiness is one of the factors that affect the company's performance (Kaplan \& Norton, 2004a). The meaning of readiness in this study is the readiness of information capital in supporting strategy execution.

The rapid development of digital technology has encouraged scholars to conduct studies investigating the effect of information capital on business performance. The results of those studies are still inconsistent. In general, the results of previous studies confirm that information capital affects 
business performance (Mikalef \& Pateli, 2017). However, different scholars (Cuevas-vargas, Estrada, \& Larios-Gome, 2016) revealed inconsistent results. A study by Vitale (1986) showed that the system and information technology provide only a limited advantage for innovators before being imitated by their competitors. Although information capital investment will improve the current competitive position, the cost will also increase. This information capital investment raises the switching costs and many companies do not get benefit from the increased switching costs (Mahmood \& Mann, 1993). This study uses the construct of human capital readiness which has a more specific definition and meaning.

This study introduces online market orientation as a mediating variable on information capital readiness-business performance relationship because the rapid development of Internet technology significantly increases the connectedness of people around the world. The digital era has been opening opportunities for people in doing online business at any time and from any place with cheaper costs (Verhoef et al., 2017). Many companies have taken advantage of Internet development by implementing online market orientation to boost their business performance (Giotopoulos et al., 2017).

The rapid development of MSMEs in Indonesia needs proper management to create a sustainable business performance. Until now, the MSMEs still have many problems, including the utilization of information and communication technology to access a wider market and external sources of capital (Napitupulu et al., 2018). Dahliah, Kurniawan, and Putra (2020) stated that the government's strategies and policy need to focus on the development of SMEs in Indonesia. We argue that an online market orientation strategy will provide a good solution for increasing business performance. In Indonesia, MSMEs also play important role in the business of commercial banks (Yudaruddin, 2020).

\section{Literature Review and Hypotheses}

The resource-based view (RBV) states that a competitive advantage can be achieved by developing internal resources for long-term survival. The high status of information capital readiness and online market orientation strategy are two important internal resources for achieving sustained business performance. Performance is important in every organization and is influenced by many factors (Singh, Burgess, \& Heap, 2016).

The synergy between information capital readiness and online market orientation is expected to improve business performance. Performance needs to be measured comprehensively not only from financial aspects but also from non-financial aspects. Non-financial aspects are sources for improving financial performance (Zaman, 2017).
Many companies compete by applying information and communication technology throughout the business process as a way to improve their competitiveness and business performance (Andjarwati \& Hermanto, 2018). According to $\mathrm{Wu} \& \mathrm{Hu}$ (2012), information capital includes information technology infrastructure and applications supporting the organizations' activities. Kaplan \& Norton (2004b) also stated that the readiness status of information capital is the most important raw material for creating value in the era of information. It provides useful information and knowledge for better decision-making. Information capital readiness refers to the readiness level of information capital in supporting the organization's strategy (Kaplan \& Norton, 2004b).

The higher the information capital readiness, the wider market opportunities because the company will have both the online market and offline market (Nakasone, Torero, \& Minten, 2014). Information capital enables a company to serve customers, expand geographical reach, respond to competitive pressures, and reduce operational costs (Wymer \& Regan, 2005). Online market orientation requires information capital readiness in improving business performance through changes in marketing business processes (Quinton et al., 2018). Market orientation is an organizational culture that effectively and efficiently creates the behavior needed to produce value to consumers and creates superior and sustainable business performance. The previous studies show that market orientation is associated with business performance (Joensuu-Salo et al., 2018). Market orientation, directly and indirectly, improves business performance (Verhoef et al., 2017).

\subsection{Information Capital Readiness and Business Performance}

Scholars have investigated the impact of information capital on business performance and the results are inconsistent. This study employs a more specific construct, namely the information capital readiness. As stated by Kaplan and Norton (2004b), the value of intangible assets, including information capital is on the readiness. Thus, information capital readiness means the readiness status of information capital in strategy execution. The topic of information capital readiness itself is rarely researched by scholars. Several previous studies have been conducted to examine the impact of information capital on business performance (Eggers et al., 2017). the higher the readiness status of information capital, the higher the business performance. Based on the previous arguments, the following first hypothesis is proposed:

$\boldsymbol{H}_{l}$ : Information capital readiness is positively associated with business performance 


\subsection{Information Capital Readiness and Online Market Orientation}

Today's consumers are in a vast and complex environment with various networks. Each network has features that can connect people and companies. Information and communication technology facilitate such connections and drives other types of interactions, such as transactional and social information sharing (Verhoef et al., 2017). A business needs to focus on generating and disseminating market information and then being able to effectively respond to changing markets (Kohli, 2017). Simmons, Armstrong, and Durkin (2011) stated that market orientation is used to identify the quality of market-oriented businesses, such as targeting the market, understanding customer needs, creating customer value, responding to negative feedback, and sharing customer information throughout the organization. The readiness status of information capital will determine the success of the marketing strategy, particularly online marketing orientation. Based on the previous arguments, the following second hypothesis is proposed:

$\boldsymbol{H}_{2}:$ Information capital readiness is positively associated with online market orientation

\subsection{Online Market Orientation and Business Performance}

The relationship between market orientation and performance is widely discussed by scholars (Jogaratnam, 2017). Several studies have demonstrated that online market orientation is positively related to business performance. Thus, it is potential to change the marketing strategy of MSMEs in the areas of customer relationship marketing, access to new markets, business-to-business collaboration, product creation with customers, and increased internal efficiency (Alford \& Page, 2015). Companies must develop a better and precise market orientation to pay more attention, understand and meet customer needs, to understand the economic environment they face, and to respond to changing the market and competitive environments (Levitt, 1960; Narver \& Slater, 1990; Li, Zhao, Tan, \& Liu, 2008). Social media is one of the online marketplaces where companies can communicate with their customers and business partners (Tajvidi \& Karami, 2017). By using social media, a company is expected to improve its business performance (Tajvidi \& Karami, 2017; Wang \& Gon, 2017). The higher the level of online market orientation, the higher the result in business performance. Based on the previous arguments, the following third hypothesis is proposed:
$\boldsymbol{H}_{3}:$ Online market orientation is positively associated with business performance

\subsection{Mediating Role of Online Market Orientation on Information Capital Readiness-Business Performance Relationship}

As previously discussed, information capital readiness drives business performance (Mikalef \& Pateli, 2017). Information capital readiness also plays a crucial in supporting the success of an online market orientation strategy (Verhoef et al., 2017; Kohli, 2017). Furthermore, online market orientation has been proven to improve business performance (Eggers et al., 2017). In conclusion, online market orientation mediates information capital readiness-business performance relationship. Based on the previous arguments, the following fourth hypothesis is proposed:

$\boldsymbol{H}_{4}:$ Online market orientation mediates the relationship between information capital readiness and business performance

\section{Literature Review and Hypotheses}

\subsection{Sample and data collection}

The sample was purposively derived from 1,004 MSMEs under the supervision of the Cooperatives and MSMEs Agency, East Java Province. The online and offline questionnaires were distributed to the owner/managers of those MSMEs. As many as 433 owners/managers of the MSMEs participated, and the response rate was $43 \%$.

\subsection{Definitions and Measurements}

\subsubsection{Information Capital Readiness (ICR)}

Information capital readiness is the readiness status of information capital to support the execution of the organization's strategy. Referring to Kaplan dan Norton (2004b), the construct of information capital readiness consists of four elements, namely: (1) transaction processing applications readiness that automates repetitive and routine basic transactions within a company, (2) analytic applications readiness which are applications for analyzing, interpreting, and sharing knowledge, (3) transformational applications readiness that is capable of transforming, and (4) information technology infrastructure readiness where companies invest in hardware. A 5-Likert scale was employed, ranging from "1 for strongly disagree" to " 5 for strongly agree". 
Table 1: Characteristics of Respondents

\begin{tabular}{|c|c|c|c|}
\hline \multirow{2}{*}{ Classification Data } & \multirow{2}{*}{ Sub Classification } & \multicolumn{2}{|c|}{ Frequency } \\
\hline & & Absolute & Percentage \\
\hline \multirow{4}{*}{ Type of Business } & Trading & 173 & $40 \%$ \\
\hline & Services & 26 & $6 \%$ \\
\hline & Manufacturing & 234 & $54 \%$ \\
\hline & Total & 433 & $100 \%$ \\
\hline \multirow{4}{*}{ Annual Sales } & $\leq$ IDR $300 \mathrm{M}$ (micro) & 316 & $73 \%$ \\
\hline & > IDR 300 M - IDR 2,500 M (small) & 95 & $22 \%$ \\
\hline & $>$ IDR $2,500 \mathrm{M}$ - IDR 50,000 M (medium) & 22 & $5 \%$ \\
\hline & Total & 433 & $100 \%$ \\
\hline \multirow{5}{*}{ Number of Employees } & $<5$ & 238 & $55 \%$ \\
\hline & $5-10$ & 113 & $26 \%$ \\
\hline & $11-15$ & 30 & $7 \%$ \\
\hline & $>15$ & 52 & $12 \%$ \\
\hline & Total & 433 & $100 \%$ \\
\hline
\end{tabular}

\subsubsection{Online Market Orientation (OMO)}

Online market orientation is defined as the marketing concept that facilitates the company's ability to provide superior products and services to customers using the Internet. Referring to Kohli and Jaworski (1990), the construct of market orientation consists of three components, namely: (1) market intelligence, (2) intelligence dissemination, and (3) responsiveness. Market intelligence refers to the company's ability to identify and assess future customer wants and needs. Intelligence dissemination refers to the process and level of distribution of market information within the organization formally and informally. Responsiveness is an action taken in response to intelligence created and disseminated in assessing market situations (Kohli \& Jaworski, 1990; Jaworski \& Kohli, 1993; Filieri, 2015). A 5-Likert scale was employed, ranging from "1 for strongly disagree" to " 5 for strongly agree"

\subsubsection{Business Performance (BP)}

Business performance is defined as the results achieved by the MSMEs in the last three 3 years. Business performance has traditionally focused only on financial performance, such as profitability. Focusing only on financial performance misleads real business performance (Kaplan \& Norton, 1996). This study measures the business performance by using a more comprehensive measure namely the Balanced Scorecard perspectives. As stated by Tuan (2019), the Balanced Scorecard is very useful in the Vietnamese commercial banks for measuring and improving performance and evaluating the performance of tourism firms in Hanoi (Truong, Nguyen, \& Duong, 2020). A 5-Likert scale was employed, ranging from "1 for strongly disagree" to " 5 for strongly agree"

\subsubsection{Use of PLS-SEM}

To test the hypotheses, the partial least square-structural equation modeling (PLS-SEM) was employed using the WarpPLS 5.0 software. The PLS-SEM was chosen because of the following reasons: (1) it can simultaneously analyze both direct and indirect effects; (2) it does not require normality assumptions; (3) it also allows very complex models with many latent variables and indicators, prediction-oriented analysis and big data (Rigdon, 2012); and as suggested by Sarstedt, Ringle, and Hair (2017) and Rigdon (2016), it uses the composites representing formatively and reflectively measured latent variables.

\section{Results and Discussion}

\subsection{Descriptive Statistics}

The descriptive statistic is based on the interval class of $(5-1) / 5=0.8$. First, the construct of information capital readiness (ICR) indicates that the owner/managers strongly agree on the measurement items of the construct (mean = 4.363; standard deviation $=0.386$ ). Second, the construct of online marketing orientation (OMO) indicates that the owner/managers strongly agree on the measurement items of the construct (mean $=4.22$; standard deviation $=0.118$ ). Finally, the construct of business performance shows that the owner/managers agree on the measurement items of the construct $($ mean $=4.183$; standard deviation $=0.104)$. 


\subsection{Measurement Model Analysis}

Before testing the structural model, the validity and reliability of the measurement instruments were tested using the measurement model analysis. The composite reliability, convergent and discriminant validity were investigated. The ideal cut-off point of at least 0.7 was applied to each loading factor and composite reliability. All measures are significant and have the loading factors of above 0.70 . The composite reliability (CR) coefficients for the constructs are of more than the accepted level of 0.70 , suggesting that the measures are reliable (Nunnaly, 1967; Hair et al. 2013).

We employed the average variance extracted (AVE) to assess the convergent validity to see the extent to which a measurement is positively correlated with alternative measurements of the same construct. The AVEs are greater than 0.50 ensuring that the measurement error does not dominate the variance captured by the construct (Vandenbosch, 1996).

The discriminant validity was evaluated by comparing the square roots of AVEs with the correlation between constructs to describe the extent to which constructs are different from other constructs based on empirical standards. When the square root of the AVE of a construct is greater than the correlation between the construct with another construct, then it is valid (Fornell \& Larcker, 1981). The correlation among constructs in the off-diagonal and the square root of AVE in the diagonal indicates adequate discriminant validity. Thus, the measurement model analysis proves that the measures are reliable and valid.

\subsection{Structural Model Analysis}

Table 2 (Panel A) shows that there is a positive and significant relationship between information capital readiness (ICR) and business performance (BP). This result indicates that the first hypothesis $\left(\mathrm{H}_{1}\right)$ stating that information capital readiness is positively associated with business performance, is supported. Table 2 (Panel B) demonstrates that information capital readiness is positively associated with business performance. This result proves that the second hypothesis $\left(\mathrm{H}_{2}\right)$ stating that information capital readiness is positively associated with online market orientation, is supported. Further, the result also shows that online market orientation is positively associated with business performance. This result proves that the third hypothesis $\left(\mathrm{H}_{3}\right)$ stating that online market orientation is positively associated with business performance, is also supported.

The variance accounted for (VAF) was employed to examine the mediating effect of online market orientation on the relationship between information capital readiness and business performance. The value of the VAF is 0.4068 or $48.68 \%$. This indicates that online market orientation partially mediates information capital readiness-business performance relationship. Thus, this result supports the fourth hypothesis $(\mathrm{H} 4)$ stating that online market orientation mediates the relationship between information capital readiness and business performance.

Table 2: Structural Model Analysis

\begin{tabular}{|c|c|c|c|}
\hline \multicolumn{4}{|c|}{ Panel A: Direct effect before introducing $\mathrm{OMO}$ as a mediating variable } \\
\hline \multirow[t]{2}{*}{ Variable } & \multicolumn{2}{|c|}{ Path to } & \\
\hline & \multicolumn{2}{|c|}{$\mathrm{BP}$} & \\
\hline ICR & \multicolumn{2}{|c|}{$0.42^{* * *}$} & Significant, $\mathrm{H} 1$ : Supported \\
\hline $\mathrm{R}^{2}$ & \multicolumn{2}{|c|}{0.17} & \\
\hline \multicolumn{4}{|c|}{ Panel B: Direct effect after introducing $\mathrm{OMO}$ as a mediating variable } \\
\hline \multirow[t]{2}{*}{ Variable } & \multicolumn{2}{|c|}{ Path to } & \\
\hline & $\mathrm{OMO}$ & $\mathrm{BP}$ & \\
\hline ICR & $0.45^{* * *}$ & $0.15^{\star \star \star}$ & Significant, H2: Suported \\
\hline $\mathrm{OMO}$ & & $0.64^{* * *}$ & Significant, H3: Supported \\
\hline $\mathrm{R}^{2}$ & 0.20 & 0.51 & \\
\hline \multicolumn{4}{|c|}{ Total Effect } \\
\hline \multirow[t]{2}{*}{ Variable } & \multicolumn{2}{|c|}{ Path to } & \\
\hline & ICR & $\mathrm{BP}$ & $\mathrm{OMO}$ \\
\hline $\mathrm{BP}$ & $0.44^{\star * *}$ & & $0.64^{* * *}$ \\
\hline OMO & $0.45^{* * *}$ & & \\
\hline
\end{tabular}

Note: ${ }^{* * *} p$-value $<0.01$ 


\subsection{Discussions}

This study employs the construct of human capital readiness which has a more specific definition and meaning and is rarely researched by scholars. The readiness refers to the readiness status of information capital to support strategy execution as stated by Kaplan \& Norton (2004b). As theoretically expected, the result of this study supports the first hypothesis $\left(\mathrm{H}_{1}\right)$. This result is in line with the previous study of Kaplan and Norton (2004b). This implies that the owners/managers of MSMEs in the East Java province need to enhance their readiness status of information capital to increase their business performance.

The second hypothesis $\left(\mathrm{H}_{2}\right)$ stating that information capital readiness is positively associated with online market orientation is supported. The result of this study provides empirical evidence that the readiness status of information capital in the MSMEs, East Java affects the market orientation strategy. This supports the previous studies of scholars regarding the important role of information and communication technology in the success of marketing strategy, particularly online marketing orientation strategy (Kohli, 2017).

The third hypothesis $\left(\mathrm{H}_{3}\right)$ stating that online market orientation is positively associated with business performance, is supported. This study confirms the results of previous studies of the role of market orientation on enhanced communication performance and business performance (Wang, Pauleen, \& Zhang, 2016), financial performance (Popa, Soto-acosta, \& Perez 2016), and export-oriented market performance (Gregory, Ngo, \& Karavdic, 2017). The result of this study provides additional empirical evidence that online market orientation affects business performance. This also implies that the stakeholders of MSMEs should assist the MSMEs' owners/managers to have an online market orientation strategy to enhance business performance.

The result of the fourth hypothesis $\left(\mathrm{H}_{4}\right)$ testing shows that online market orientation partially mediates the relationship between information capital readiness and business performance. This suggests that owners/managers of the MSMEs need to prepare their information capital readiness. The higher the status of intellectual capital readiness, the greater the chance for success in executing a market orientation strategy, and then the higher the business performance of MSMEs. In the digital era, the MSMEs should take the opportunities to enlarge their market using online business at any time and from any place with cheaper costs.

\section{Conclusion}

This study aims to examine the effect of information capital readiness on business performance. If so, whether online market orientation mediates the information capital readiness-business performance relationship. All hypotheses of this study are supported. In summary, (1) the information capital readiness is positively associated with business performance (2) information capital readiness is positively associated with online market orientation (3) online market orientation is positively associated with business performance, and (4) online market orientation partially mediates the relationship between information capital readiness and business performance.

This study has several limitations as follows: (1) it focuses on the MSMEs in the East Java Province, Indonesia. Future research should address this issue by conducting studies in other provinces or countries to test the validity of the same model. (2) This study uses a questionnaire survey. This may be criticized for the perceptual bias.

\section{References}

Alford, P., \& Page, S. J. (2015). Marketing technology for adoption by small businesses. The Service Industries Journal, 35(11-12), 655-669. https://doi.org/10.1080/02642069.2015.1062884

Andjarwati, T., \& Hermanto, A. (2018). Gap analysis and measurement of information technology readiness for improvement of competitive capabilities to small and medium enterprises in East Java. In: International Conference on Economics, Business and Economic Education (ICE-BEES) 2018 (pp. 12-26). Semarang City, Central Java, Indonesia, July 17-18. doi:10.18502/kss.v3i10.3115

Cuevas-vargas, H., Estrada, S., \& Larios-gómez, E. (2016). The effects of ICTs as innovation facilitators for greater business performance. Evidence from Mexico. Procedia - Procedia Computer Science, 91, 47-56. https://doi.org/10.1016/j. procs.2016.07.040.

Dahliah, D., Kurniawan, A., \& Putra, A. H. P. D. K. (2020). Analysis and Strategy of Economic Development Policy for SMEs in Indonesia. Journal of Asian Finance, Economics, and Business, 7(5), 103-110. https://doi.org/10.13106/jafeb.2020. vol7.no5.103

Eggers, F., Hatak, I., Kraus, S., \& Niemand, T. (2017). Technologies that support marketing and market development in SMEsEvidence from social networks. Journal of Small Business Management, 55(2), 270-302. https://doi.org/10.1111/jsbm.12313

Filieri, R. (2015). From market-driving to market-driven: An analysis of Benetton's strategy changes and its implications for long-term performance. Marketing Intelligence and Planning, 33(3), 238-257.

Fornell, C., \& Larcker, D. F. (1981). Evaluating structural equation models with unobservable variables and measurement error. Journal of Marketing Research, 18(1), 39-50. https://doi. org $/ 10.2307 / 3151312$

Giotopoulos, I., Kontolaimou, A., Korra, E., \& Tsakanikas, A. (2017). What drives ICT adoption by SMEs? Evidence from a 
large-scale survey in Greece. Journal of Business Research, 81, 60-69. https://doi.org/10.1016/j.jbusres.2017.08.007

Gregory, G. D., Ngo, L. V., \& Karavdic, M. (2017). Developing e-commerce marketing capabilities and efficiencies for enhanced performance in business-to-business export ventures. Industrial Marketing Management, 78(2019), 146-157. https:// doi.org/10.1016/j.indmarman.2017.03.002

Hair, J .F., Black, W. C., Babin, B. J., \& Anderson, R. E. (2013), Multivariate data analysis (7th ed.), Harlow, UK: Pearson Education Limited

Jaworski, B. J., \& Kohli, A. K. (1993). Market orientation: antecedents and consequences. Journal of Marketing, 57(3), 53-70. https://doi.org/10.2307/1251854

Joensuu-Salo, S., Sorama, K., Viljamaa, A., \& Varamäki, E. (2018). Firm performance among internationalized SMEs: The interplay of market orientation, marketing capability, and digitalization. Administrative Sciences, 8, 31. https://doi. org/10.3390/admsci8030031.

Jogaratnam, G. (2017). How organizational culture influences market orientation and business performance in the restaurant industry. Journal of Hospitality and Tourism Management, 31, 211-219. https://doi.org/10.1016/j.jhtm.2017.03.002

Kaplan, R. S., \& Norton, D. P. (1996). The balanced scorecardtranslating strategy into action. Boston, MA: Harvard Business School Press.

Kaplan, R. S., \& Norton, D. P. (2004a). Measuring the strategic readiness of intangible assets. Harvard Business Review, 82(2), 52-63.

Kaplan, R. S., \& Norton, D. P. (2004b). Strategy maps: Converting intangible assets into tangible outcomes. Boston, MA: Harvard Business School Press.

Kohli, A. K., \& Jaworski, B. J. (1990). Market orientation: the construct, research propositions, and managerial implications. Journal of Marketing, 54(20), 1-18. https://doi. org/10.1177/002224299005400201

Kohli, A. K. (2017). Market orientation in a digital world, Global Business Review, 18(3), S203-S205.

Levitt, T. (1960). Marketing myopia. Harvard Business Review, 38(July-August), 45-56.

Li, Y., Zhao, Y., Tan, J., \& Liu, Y. (2008). Moderating effects of entrepreneurial orientation on market orientation-performance linkage: Evidence from Chinese small firms. Journal of Small Business Management, 46(1), 113-133. https://doi.org/10.1111/ j.1540-627X.2007.00235.x

Lioukas, C. S., Reuer, J. J. \& Zollo, M. (2016). Effects of information technology capabilities on strategic alliances: Implications for the resource-based view. Journal of Management Studies, 53(2), 161-183. https://doi.org/10.1111/joms.12179

Mahmood, M. A., \& Mann, G. J. (1993). Measuring the organizational impact of information technology investment: An exploratory study. Journal of Management Information
Systems, 10(1), 97-122, https://doi.org/10.1080/07421222.199 3.11517992

Mikalef, P., \& Pateli, A. (2017). Information technology-enabled dynamic capabilities and their indirect effect on competitive performance: Findings from PLS-SEM and fsQCA. Journal of Business Research, 70, 1-16. https://doi.org/10.1016/j. jbusres.2016.09.004

Nakasone, E., Torero, M., \& Minten, B. (2014). The power of information: The ICT revolution in agricultural development. Annual Review of Resource Economics, 6, 533-550. https://doi. org/10.1146/annurev-resource-100913-012714

Napitupulu, D., Syafrullah, M., Rahim, R., Abdullah, D. \& Setiawan, M. (2018). Analysis of user readiness toward ICT usage at the small and medium enterprises in South Tangerang. Journal of Physics Conference Series, 1007(1), 12-42. https:// doi.org/10.1088/17426596/1007/1/012042/meta

Narver, J. C., \& Slater, S. F. (1990). The effect of a market orientation on business profitability. Journal of Marketing, 54(4), 20-35. https://doi.org/10.2307/1251757

Nunnaly, J. C. (1967). Psychometric theory. New York, NY: McGraw-Hill.

Popa, S., Soto-acosta, P., \& Perez-gonzalez, D. (2016). An investigation of the effect of electronic business on the financial performance of Spanish manufacturing SMEs. Technological Forecasting and Social Change, 136, 355-362. https://doi. org/10.1016/j.techfore.2016.08.012

Quinton, S., Canhoto, A., Molinillo, S., Pera, R., \& Budhathoki, T. (2018). Conceptualizing a digital orientation: Antecedents of supporting SME performance in the digital economy. Journal of Strategic Marketing, 26, 427-439. https://doi.org/10.1080/09 65254X.2016.1258004.

Rigdon, E. (2016). Choosing PLS path modeling as an analytical method in European management research: A realist perspective. European Management Journal, 34. https://doi. org/10.1016/j.emj.2016.05.006.

Rigdon, E. E. (2012). Rethinking partial least squares path modeling: in praise of simple methods. Long Range Planning, 45(5-6), 341-358. https://doi.org/10.1016/j. 1rp.2012.09.010

Sarstedt, M., Ringle, C., \& Hair, J. (2017). Partial Least Squares Structural Equation Modeling (PLS-SLM). In: Handbook of Market Research, Ch 15, Springers. https://doi. org/10.1007/978-3-319-05542-8_15-1.

Simmons, G., Armstrong G. A., \& Durkin, M. G. (2011) An exploration of small business website optimization: Enablers, influencers, and an assessment approach. International Small Business Journal, 29(5), 534-561. https://doi. org/10.1177/0266242610369945

Singh, S., Burgess, T., \& Heap, J. (2016). Managing performance and productivity for organizational competitiveness. International Journal of Productivity and Performance Management, 65. DOI:10.1108/IJPPM-05-2016-0090. 
Tajvidi, R., \& Karami, A. (2017). The effect of social media on firm performance. Computers in Human Behavior. article in press. https://doi.org/10.1016/j.chb.2017.09.026

Truong, D. D., Nguyen, H., \& Duong, T. Q. L. (2020). Factors influencing a balanced scorecard application in evaluating the performance of tourist firms. Journal of Asian Finance, Economics, and Business, 7(5), 217-224. https://doi. org/10.13106/jafeb.2020.vol7.no5.217

Tuan, T. T. (2019). The Impact of Balanced Scorecard on Performance: The Case of Vietnamese Commercial Banks. Journal of Asian Finance, Economics, and Business. 7(1), 7179. https://doi.org/10.13106/jafeb.2020.vol7.no1.71

Vandenbosch, M. B. (1996). Confirmatory compositional approaches to the development of product spaces. European Journal of Marketing, 30(3), 23-46. https://doi. org/10.1108/03090569610107418

Verhoef, P., Broekhuizen, T., Bart, Y., Bhattacharya, A., Dong, J., Fabian, N., \& Haenlein, M. (2019). Digital transformation: A multidisciplinary reflection and research agenda. Journal of Business Research, 2(2019), 1-4. https://doi.org/10.1016/j. jbusres.2019.09.022.

Vitale, M., Ives, B., \& Beath, C. M. (1986). Linking information technology and corporate strategy: an organizational view. In: Proceedings of the 7th International Conference on Information Systems, ICIS 1986 (30). San Diego, California, USA. https:// aisel.aisnet.org/icis1986/30

Wang, W. Y. C., Pauleen, D. J., \& Zhang, T. (2016). Industrial marketing management. How social media applications affect
B2B communication and improve business performance in SMEs. Industrial Marketing Management, 54, 4-14. https://doi. org/10.1016/j.indmarman.2015.12.004

Wang, Z., \& Gon, H. (2017). Can social media marketing improve customer relationship capabilities and firm performance? Dynamic capability perspective. Journal of Interactive Marketing, 39, 15-26. https://doi.org/10.1016/j. intmar.2017.02.004

Wu, I. L., \& Hu, Y. P. (2012). Examining knowledge management enabled performance for hospital professionals: A dynamic capability view and the mediating role of process capability. Journal of the Association for Information Systems, 13(12), 313-344. https://doi.org/10.17705/1jais.00319

Wymer, S., \& Regan, E. (2011). Influential factors in the adoption and use of E-Business and E-Commerce Information Technology (EEIT) by small \& medium businesses. Journal of Electronic Commerce in Organizations, 9, 56-82. https://doi. org/10.4018/jeco.2011010104.

Yudaruddin, R. (2020). Determinants of micro-, small- and mediumsized enterprise loans by commercial banks in Indonesia. Journal of Asian Finance, Economics, and Business, 7(9), 1930. https://doi.org/10.13106/jafeb.2020.vol7.no9.019

Zaman, M. (2017). The role of financial and non-financial evaluation measures in the process of management control over foreign subsidiaries-empirical evidence in Slovene multinational companies. Management: Journal of Contemporary Management Issues, 9(2), 53-73. https://hrcak.srce.hr/184526 